\title{
Proces doganiania rozwoju gospodarczego krajów OECD oraz rola bezpośrednich inwestycji zagranicznych w tym procesie
}

\begin{abstract}
Artykuł składa się z dwóch części. W pierwszej opisujemy poziom rozwoju gospodarczego 51 krajów związanych z Organizacją Współpracy Cospodarczej i Rozwoju (OECD), wykorzystując w tym celu PKB per capita. Proponujemy podział tych krajów na trzy grupy: wysoko, średnio i nisko rozwinięte. Następnie, posługując się średniorocznym tempem wzrostu w okresie 2005-2016, wyróżniamy kraje: rozwijające się, w stagnacji i recesji. Łącząc obie te zmienne, proponujemy wyróżnić 7 podgrup krajów: od wysoko rozwiniętych uciekających, poprzez wysoko rozwinięte stabilne i doganiane do krajów średnio i nisko rozwiniętych doganiających. W drugiej części artykułu analizujemy bezpośrednie inwestycje zagraniczne (FDI) w ujęciu globalnym, krajów OECD i Unii Europejskiej (EU), w szczególności badamy przepływy kapitałowe między wyszczególnionymi wcześniej trzema (wysoko, średnio i nisko rozwiniętymi) grupami krajów OECD. W ostatniej części, prezentujemy modele regresji potwierdzające dodatnie sprzężenie zwrotne między FDI i wzrostem gospodarczym. Świadczą one o procyklicznym działaniu bezpośrednich inwestycji zagranicznych.
\end{abstract}

Słowa kluczowe: kraje wysoko, średnio i nisko rozwinięte, OECD, kraje uciekające, doganiające i doganiane, bezpośrednie inwestycje zagraniczne.

\section{Wprowadzenie}

Nowa Ekonomia Strukturalna (New Structural Economics - NSE) jest teoretyczną bazą polityki gospodarczej państwa wspierającego wzrost gospodarczy, głównie dedykowaną dla gospodarek doganiających ${ }^{1}$. Doganianie jest atrybutem wszelkich wyścigów. Skłoniło to nas do zbadania, jak wygląda wyścig krajów w pogoni za najbardziej rozwiniętymi. Analizę ograniczamy do bazy danych 51 krajów związanych z Organizacją Współpracy Gospodarczej i Rozwoju (Organisation for Economic Co-operation and Developp-

1 Świadczy o tym chociażby tytuł artykułu J.Y. Lina „Nowa Ekonomia Strukturalna dla gospodarek doganiających" (zob. Lin, Nowak 2017). 
ment - OECD). Jest to rodzaj sprawozdania sportowego $\mathrm{z}$ wyścigu tych krajów w procesie rozwoju gospodarczego, jaki odbył się w latach 2005-2016.

Państwa powiązane z OECD mają różny status: 36 państw ma status członka; Polska przystąpiła do tej Organizacji w roku 1996; osiem państw aspiruje do członkostwa w OECD (np. Federacja Rosyjska), pozostałe uwzględnione w badaniu państwa mają podpisane umowy o wzmożonej współpracy (https:// data.oecd.org). Przynależność do OECD jest pewną nobilitacją państwa i ma niewątpliwy wpływ na ocenę ryzyka kraju i jego rating². Pełna lista uwzględnionych w badaniu krajów znajduje się na rysunku 1.

\section{Stopień i tempo rozwoju krajów OECD}

Za jedyny miernik poziomu rozwoju gospodarczego kraju przyjmujemy Produkt Krajowy Brutto na głowę mieszkańca (Gross Domestic Product per capita - GDP per capita). Jesteśmy świadomi jego ograniczeń informacyjnych, nie ma jednak innego tak bardzo syntetycznego wskaźnika. Rysunek 1 prezentuje poziom PKB per capita w krajach OECD w roku 2005, a więc na starcie opisywanego wyścigu. Przyznać należy, że rozpiętość poziomu PKB per capita jest bardzo wysoka. Najwyższy - 80 tys. USD jest w Luxemburgu, najniższy 707 USD - w Indiach. Proponujemy podział krajów OECD, uwzględniający PKB per capita, na trzy grupy:

- 19 krajów wysoko rozwiniętych PKB per capita, 30-80 tys. USD,

- 21 krajów średnio rozwiniętych PKB per capita, 5-30 tys. USD,

- 11 krajów nisko rozwiniętych PKB per capita, 700-5 tys. USD.

W pierwszej grupie na uwagę zasługuje 6 krajów o najwyższym poziomie PKB per capita: Luksemburg - 80 tys. USD (pozycja 1), Norwegia - 68 tys. USD (pozycja 2), Islandia - 58 tys. USD (pozycja 3), Szwajcaria - 55 tys. USD (pozycja 4), Irlandia - 50 tys. USD (pozycja 5), Dania - 49 tys. USD (pozycja 6). Kraje te, jak się wydaje, mają pewne wspólne cechy. Są to relatywnie małe kraje zachodnio-europejskie, posiadające wielowiekową tradycję gospodarki kapitalistycznej, które ominęły pożogi wojenne, w szczególności straty w II wojnie światowej. Stany Zjednoczone znajdują się na 7 miejscu (42 tys. USD), Niemcy zaś na miejscu 17 (35 tys. USD). Grupę krajów najbardziej rozwiniętych zamykają Włochy (31 tys. USD).

2 Przed przyjęciem Bazylei II, w obliczaniu współczynników wypłacalności banków dla należności od instytucji finansowych działających w krajach OECD przyjmowano wagę ryzyka 0,2 , podczas gdy dla pozostałych wagę ryzyka 0,5 . 


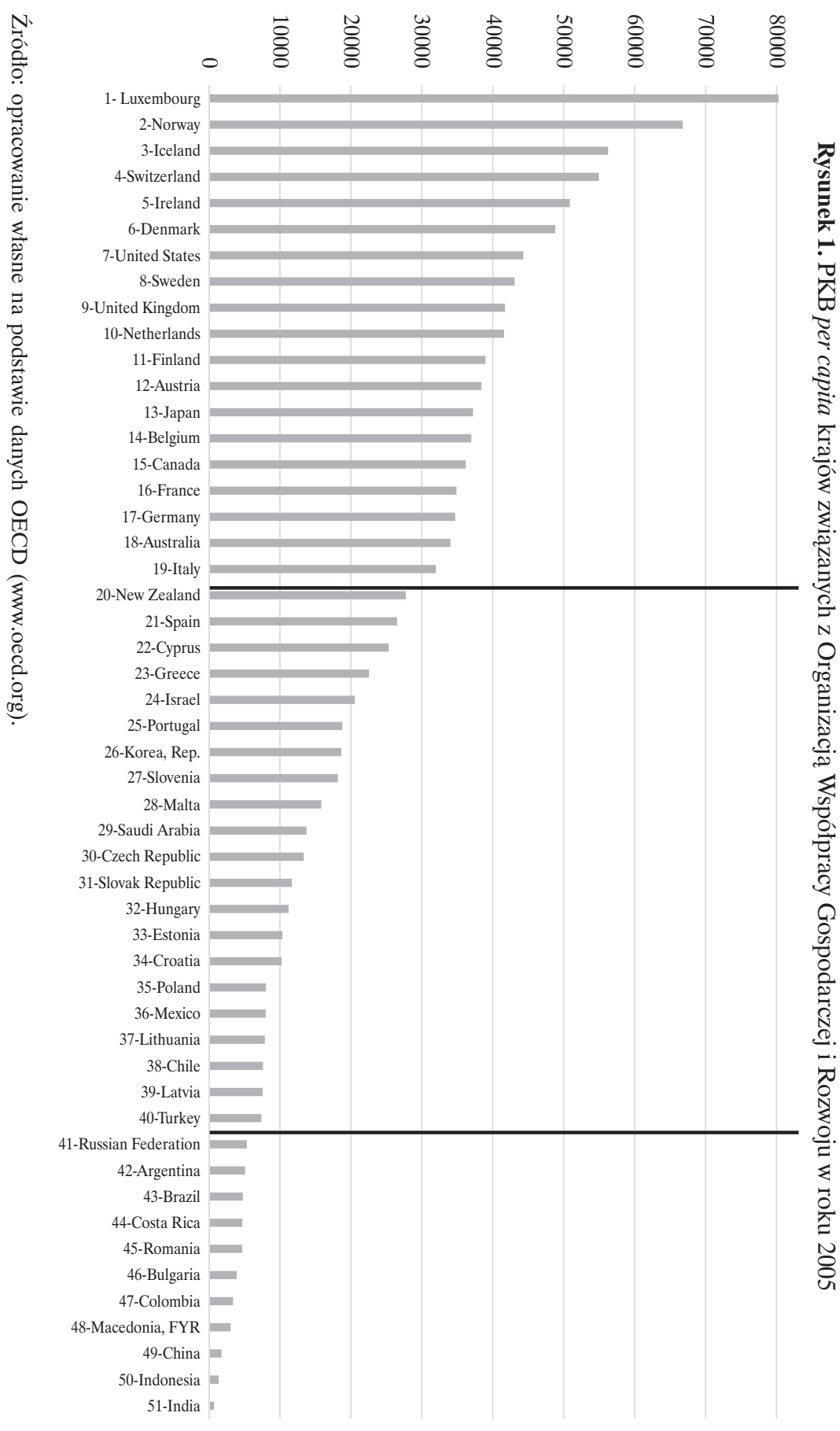

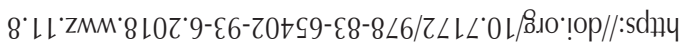


Drugą grupę krajów średnio rozwiniętych otwiera Nowa Zelandia (28 tys. USD), zamyka natomiast Turcja (7 tys. USD). Grupę tę tworzą południowo europejskie kraje zaliczane do grupy PIGS (Portugal, Italy, Greece, Spain) oraz kraje określane jako emerging markets: z Europy Środkowej i Wschodniej (w tym Polska -8 tys. USD; pozycja 35), z Azji (Turcja - 7 tys. USD; pozycja 36) i z Ameryki Południowej (Meksyk - 8 tys. USD; pozycja 40).

Do trzeciej grupy krajów najmniej rozwiniętych należą duże kraje z Europy i Azji: Federacja Rosyjska - 500 USD (pozycja 41), Chiny - 200 USD (pozycja 49), Indonezja - 150 USD (pozycja 50), Indie - 100 USD (pozycja 51) oraz Ameryki Południowej: Argentyna - 400 USD (pozycja 42), Brazylia - 300 USD (pozycja 43).

Na rysunku 2 prezentujemy średnioroczne stopy wzrostu PKB w cenach stałych $(r)$ w 51 badanych krajach w latach 2005-2016. W skali globalnej w okresie tym, w latach 2005-2007, była wysoka i poprawiająca się koniunktura gospodarki, załamanie i kryzys w latach 2008-2010 oraz przezwyciężanie kryzysu i powrót do lepszej koniunktury w latach 2011-2016. Poszczególne kraje przechodziły to w sposób istotnie zróżnicowany. Najwyższe tempo wzrostu osiągały: Chiny - 10,4\%; Indie - 8,4\%; Indonezja - 6,1\%; Turcja - 5,0\%. Dwa kraje miały w tym okresie stopy ujemne: Grecja $-1,9 \%$; Włochy $-0,2 \%$. Polska ze średnioroczną stopą wzrostu 4,1\% znalazła się na 13 miejscu po Chile $(4,2 \%)$ i przed Maltą (3,9\%). Uwzględniając średnioroczne tempo wzrostu, podzieliliśmy badane kraje na trzy grupy:

- kraje rozwijające się (29) $r=(+2+10 \%)$;

- kraje w stagnacji (15) $r=(+1+2 \%)$;

- kraje w recesji $(7) r=(-1+1 \%)$.

Zdecydowanie największa liczba krajów (29) odnotowała istotny wzrost gospodarczy. Co bardzo ważne z punktu widzenia NSE są to kraje z grupy najsłabiej i średnio rozwiniętych. Tylko 7 krajów odnotowało procesy stagnacji i recesji są to głównie: Japonia $(0,07 \%)$ oraz wybrane kraje europejskie: Finlandia (0,08\%), Cypr (1,0\%), Portugalia $(0,01 \%)$, Włochy $(-0,02 \%)$ i Grecja $(-1,9 \%)$. 


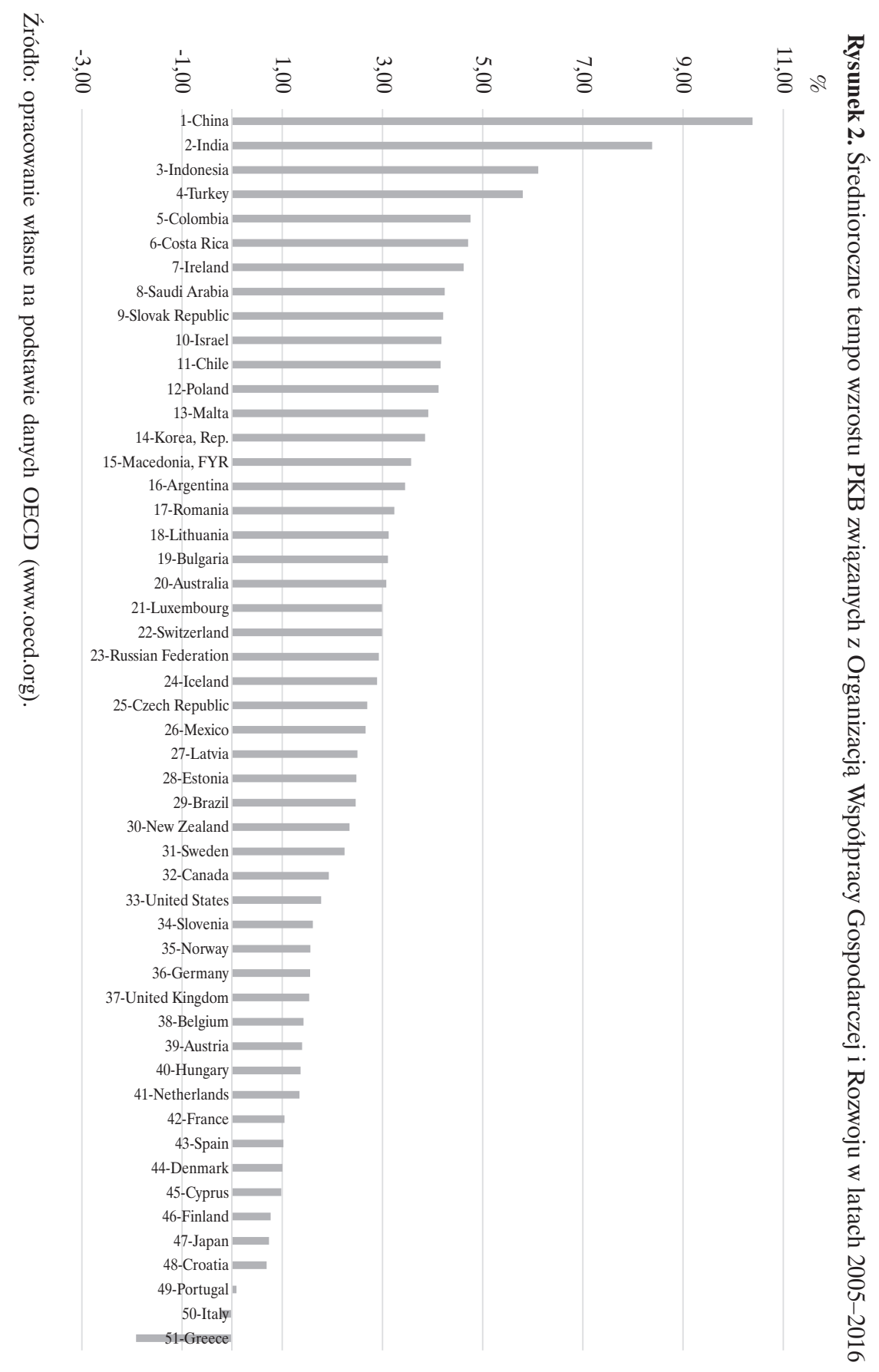

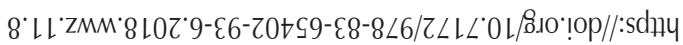


Uwzględniając dwa kryteria: poziom PKB per capita na początku okresu (2005 r.) oraz średnioroczne tempo wzrostu $(r)$ w okresie 2005-2016 możemy wydzielić w ramach 51 badanych krajów siedem ich grup.

Tabela 1. Klasyfikacja krajów OECD z uwzględnieniem PKB per capita w roku 2005, tempa wzrostu gospodarczego (r) w latach 2005-2016 oraz długoterminowego credit ratingu dotyczącego zobowiązań wyrażonych w walucie obcej przez S\&P

\begin{tabular}{|c|c|c|c|c|}
\hline Lp. & $\begin{array}{l}\text { Grupa } \\
\text { krajów }\end{array}$ & Kryteriumn & $\begin{array}{l}\text { Liczba } \\
\text { krajów }\end{array}$ & $\begin{array}{c}\text { Lista krajów wraz } \\
\mathbf{z} \text { długoterminowym } \\
\text { ratingiem emitenta dotyczącym } \\
\text { zobowiązań wyrażonych w walucie obcej } \\
\text { publikowanym przez S\&P }\end{array}$ \\
\hline 1a & $\begin{array}{l}\text { Rozwinięte } \\
\text { uciekające }\end{array}$ & $\begin{array}{l}\mathrm{PKB}>30 \text { tys. USD } \\
\mathrm{r}>2 \%\end{array}$ & 5 & $\begin{array}{l}\text { Luksemburg AAA, Islandia AA-, } \\
\text { Irlandia A+, Szwecja AAA, } \\
\text { Australia AAA }\end{array}$ \\
\hline $1 \mathrm{~b}$ & $\begin{array}{l}\text { Rozwinięte } \\
\text { stabilne }\end{array}$ & $\begin{array}{l}\text { PKB }>30 \text { tys. USD } \\
\mathrm{r}=(+1+2 \%)\end{array}$ & 11 & $\begin{array}{l}\text { Norwegia AAA, Szwajcaria AAA, } \\
\text { Dania AAA, Stany Zjednoczone AA+, } \\
\text { Wielka Brytania AA, Holandia AAA, } \\
\text { Austria AA+, Belgia AA, Kanada AAA, } \\
\text { Francja AA, Niemcy AAA }\end{array}$ \\
\hline 1c & $\begin{array}{l}\text { Rozwinięte } \\
\text { dościgane }\end{array}$ & $\begin{array}{l}\text { PKB }>30 \text { tys. USD } \\
r=(-1+1 \%),\end{array}$ & 3 & $\begin{array}{l}\text { Finlandia AA+, Japonia A+, } \\
\text { Włochy BBB- }\end{array}$ \\
\hline $2 \mathrm{a}$ & $\begin{array}{l}\text { Średniorozwinięte } \\
\text { dościgające }\end{array}$ & $\begin{array}{l}\mathrm{PKB}=30 \text { tys. USD } \\
-7 \text { tys. USD } \\
\mathrm{r}>2 \%\end{array}$ & 13 & $\begin{array}{l}\text { Nowa Zelandia AA, Izrael A+, } \\
\text { Korea Południowa AA, Malta A-, } \\
\text { Arabia Saudyjska A-, Republika } \\
\text { Czeska AA-, Republika Słowacka A+, } \\
\text { Polska BBB+, Meksyk BBB+, } \\
\text { Litwa BBB+, Chile AA, Lotwa A-, } \\
\text { Turcja BB }\end{array}$ \\
\hline $2 b$ & $\begin{array}{l}\text { Średniorozwinięte } \\
\text { stabilne }\end{array}$ & $\begin{array}{l}\text { PKB }=30 \text { tys. USD } \\
-7 \text { tys. USD } \\
r=(+1+2 \%)\end{array}$ & 4 & $\begin{array}{l}\text { Hiszpania BBB+, Słowenia A, } \\
\text { Węgry BBB-, Estonia AA- }\end{array}$ \\
\hline $2 \mathrm{c}$ & $\begin{array}{l}\text { Średniorozwinięte } \\
\text { dościgane }\end{array}$ & $\begin{array}{l}\text { PKB }=30 \text { tys. USD } \\
-7 \text { tys. USD } \\
\mathrm{r}=(-1+1 \%)\end{array}$ & 4 & $\begin{array}{l}\text { Cypr BB, Grecja B-, Portugalia BB+, } \\
\text { Chorwacja BB+ }\end{array}$ \\
\hline $3 \mathrm{a}$ & $\begin{array}{l}\text { Słaborozwinięte } \\
\text { dościgające }\end{array}$ & $\begin{array}{l}\mathrm{PKB}<7 \text { tys. USD } \\
\mathrm{r}>2 \%\end{array}$ & 11 & $\begin{array}{l}\text { Federacja Rosyjska BB+, } \\
\text { Argentyna B-, Brazylia BB, Costa } \\
\text { Rica BB-, Rumunia BBB-, } \\
\text { Bułgaria BB+, Kolumbia BBB, } \\
\text { Macedonia BB-, Chiny AA-, } \\
\text { Indonezja BB+, Indie BBB }\end{array}$ \\
\hline
\end{tabular}

Źródło: obliczenia własne na podstawie danych OECD oraz Thomson Reuters Database.

Zdecydowanie największa liczba krajów (11) wysoko rozwiniętych znalazła się w grupie gospodarek stabilnych z umiarkowanym tempem wzrostu gospo- 
darczego (1-2\%). Do krajów tych należą: Stany Zjednoczone oraz główne kraje Unii Europejskiej (EU). Wszystkie kraje słabo rozwinięte oraz większość średnio rozwiniętych znalazło się w grupie krajów doganiających (24), co, jak się wydaje, stwarza dobre perspektywy rozwoju, popularyzacji i praktycznego wykorzystania idei oraz koncepcji NSE.

Zróżnicowane tempo wzrostu gospodarczego spowodowało zmiany w klasyfikacji krajów OECD pod względem PKB per capita. Klasyfikację tę na rok 2016 prezentujemy na rysunku 3. Na pierwszym miejscu utrzymał się Luksemburg, jednak PKB per capita wzrosło do 100 tys. USD. Przyczyną tego wzrostu jest jednak nie tylko relatywnie wysokie tempo wzrostu gospodarczego tego kraju, ale również wzrost kursu EUR do USD. Na drugim miejscu znalazła się Szwajcaria (80 tys. USD), pomimo umiarkowanego tempa wzrostu. Jest to przede wszystkim efekt umocnienia się FRS względem USD. Grupę 19 krajów najbardziej rozwiniętych opuściła Francja (38 tys. USD) i Włochy (29 tys. USD). $\mathrm{Na}$ ich miejsce do grupy tej weszły: Nowa Zelandia (40 tys. USD) oraz Izrael (39 tys. USD).

W grupie krajów średnio rozwiniętych w roku 2016 na pierwszym miejscu znalazła się Francja (37 tys. USD), na drugim Włochy (29 tys. USD). Grupę tę opuścił: Meksyk (4 tys. USD) i Turcja (5 tys. USD). Dołączyły zaś do niej Argentyna (12 tys. USD) i Costa Rica (11 tys. USD). Polska, pomimo relatywnie wysokiego tempa wzrostu gospodarczego $(4,1 \%)$, spadła w tej klasyfikacji z pozycji 33 na 38, co wynika przede wszystkim ze wzrostu kursu USD w PLN.

Bardzo wysokie tempo wzrostu gospodarczego Chin (10,4\%) przesunęło ten kraj z pozycji 49 na pozycję 46 . Natomiast relatywnie wysokie tempo wzrostu w Indiach $(8,4 \%)$ i w Indonezji $(6,1 \%)$ nie przesunęło tych krajów z ostatniego i przedostatniego miejsca na liście najbogatszych krajów OECD.

Jak widać, krajowe ratingi agencji S\&P w roku 2016 są silnie skorelowane z zaproponowanym przez nas podziałem krajów OECD pod względem PKB per capita na trzy grupy. W pierwszej grupie krajów najbogatszych, poza Włochami, oceny mieszczą się w przedziale AAA - AA-. Niższa ocena Włoch (BBB-) wynika zapewne $\mathrm{z}$ wysokiego długu publicznego tego państwa (132\% PKB). Relatywnie niskie oceny Irlandii $(\mathrm{A}+)$ oraz Islandii są pokłosiem recesji tych dwóch gospodarek w okresie kryzysu 2008-2009.

Ratingi krajów w grupie średnio rozwiniętych są bardziej zróżnicowane i mieszczą się poza Grecją (B-) w przedziale AA (Nowa Zelandia) - BB (Cypr). Najniższa nota Grecji wynika z kryzysu zadłużeniowego tego państwa. Najniższe ratingi posiadają kraje $\mathrm{z}$ grupy słabo rozwiniętych i mieszczą się one w przedziale BB + (Federacja Rosyjska) - BBB- (Indie). 


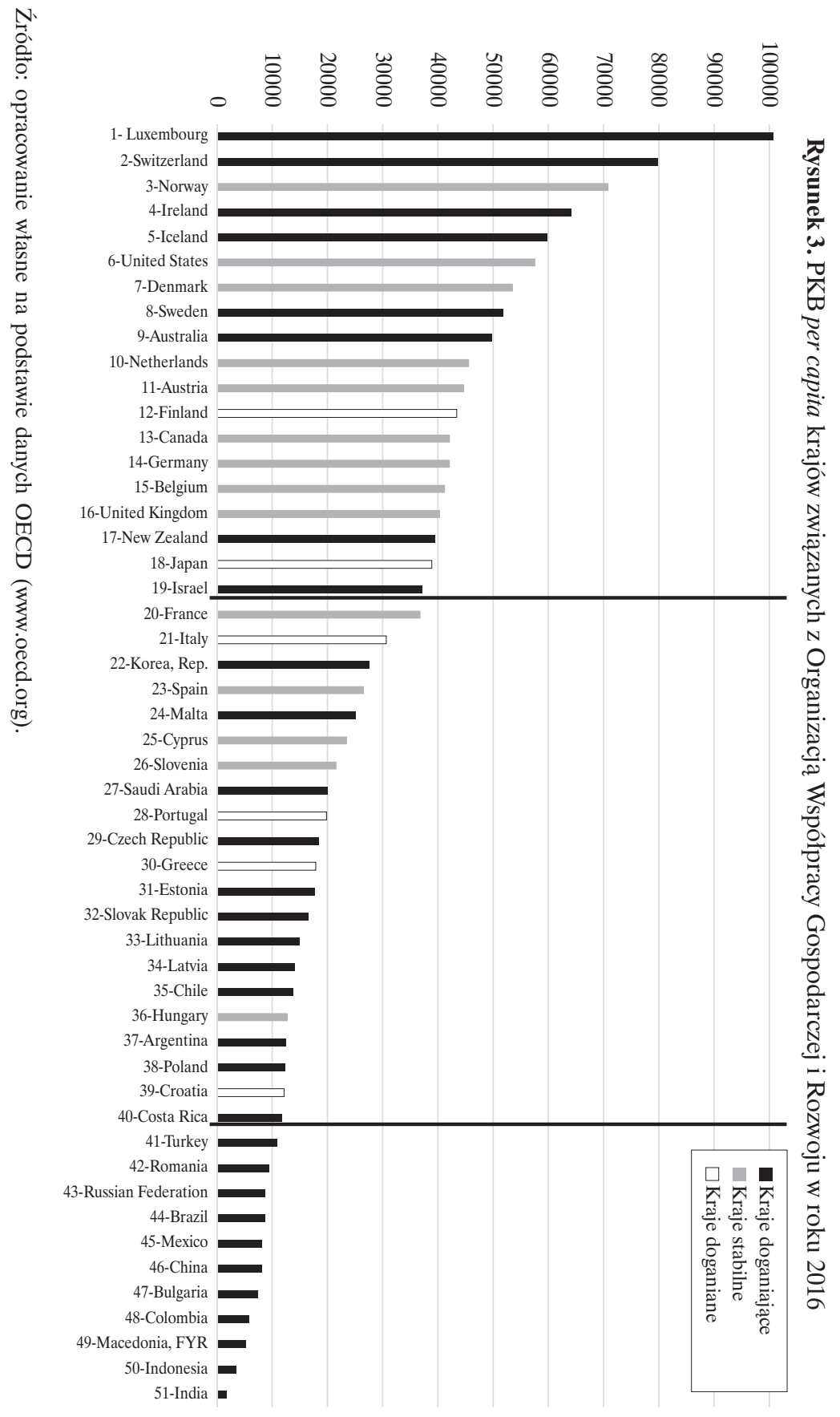




\section{Bezpośrednie inwestycje zagraniczne}

We współczesnej otwartej i zglobalizowanej gospodarce potencjał jej rozwoju niewątpliwie zależy od udziału kraju w wymianie międzynarodowej na wszystkich rynkach: towarowych, pracy i finansowych. W szczególności przeanalizujemy światowe przepływy kapitału w ramach tzw. bezpośrednich inwestycji zagranicznych (foreign direct investment - FDI). FDI są zestawiane i publikowane przez banki centralne.

Według definicji IMF i OECD są kategorią międzynarodowych inwestycji dokonywanych przez rezydenta jednego kraju (nazywanym „inwestorem bezpośrednim” lub „spółką-matką”) z zamiarem sprawowania długoterminowej kontroli w przedsiębiorstwie innego kraju (nazywanym „przedsiębiorstwem bezpośredniej inwestycji” lub „spółką-córką”). Przez długoterminową kontrolę rozumie się istnienie długoterminowych relacji między inwestorem bezpośrednim i spółką-córką, a istotny sposób oddziaływania, który daje inwestorowi bezpośredniemu efektywny głos w zarządzaniu przedsiębiorstwem, zależy od udziału inwestora bezpośredniego w kapitale spółki-córki. Minimalny próg zaangażowania kapitałowego inwestora bezpośredniego w spółce-córce ustalono na poziomie $10 \%$.

Komponentami FDI są: kapitał zakładowy (equity capital), reinwestowane zyski (reivested earnings) oraz inny kapitał (other capital). FDI w kapitał zakładowy związane są z:

- zakupem akcji, udziałów lub majątku spółki,

- aportem rzeczowym, np. w postaci maszyn i urządzeń,

- reinwestowanymi zyskami, częścią lub całością wypracowanych zysków (proporcjonalne do udziału inwestora bezpośredniego w kapitale spółki), które nie zostały wypłacone $\mathrm{w}$ formie dywidendy.

Inny kapitał to pożyczki wewnątrzkorporacyjne oraz transakcje związane $\mathrm{z}$ obsługą tego długu. Istotą FDI jest transfer nie tylko kapitału, lecz również pracy (np. udział przedstawicieli w zarządzie spółki-córki) i wiedzy (technologicznej, marketingowej i organizacyjnej).

Bezpośrednie inwestycje zagraniczne w krajowych bilansach płatniczych występują w następujących ujęciach:

- bezpośrednie inwestycje krajowe za granicą:

- napływ (inflow) - nabyte (objęte) przez rezydentów za granicą akcje (udziały, majątek) + reinwestowane zyski + przyrost długu spółek zagranicznych u rezydentów; 
- odpływ (outflow) - sprzedane przez rezydentów zagraniczne akcje (udziały - majątek) + wypłacone rezydentom dywidendy przez spółki zagraniczne + spłata długu przez spółki zagraniczne rezydentom;

- stan (stocs) - posiadane przez rezydentów na koniec roku (kwartału) akcje (udziały, majątek) + niespłacone długi spółek zagranicznych względem rezydentów.

- bezpośrednie inwestycje zagraniczne w kraju:

- napływ (inflow) - nabyte przez podmioty zagraniczne w kraju akcje (udziały, majątek) + reinwestowane przez podmioty zagraniczne w kraju zyski + przyrost długu spółek krajowych względem podmiotów zagranicznych;

- odpływ (outflow) - sprzedane przez podmioty zagraniczne akcje (udziały, majątek) + wypłacone przez rezydentów podmiotom zagranicznym dywidendy + spłata długu rezydentów dla spółek zagranicznych;

- stan (stocs) - posiadane przez podmioty zagraniczne w kraju akcje (udziały, majątek) + niespłacone przez rezydentów względem podmiotów zagranicznych długi.

Zgodnie z definicją OECD oraz Banku Światowego w statystykach międzynarodowych saldo napływu netto (net inflow) w ramach FDI to wartość bezpośrednich inwestycji dokonanych przez inwestorów zagranicznych w gospodarce sprawozdającej. Saldo wydatków netto (net outflow) natomiast to wartość bezpośrednich inwestycji zagranicznych dokonywanych przez rezydentów gospodarki sprawozdającej na zewnętrzne gospodarki. Inwestycje bezpośrednie, zwane również inwestycjami bezpośrednimi w gospodarce sprawozdającej, obejmują wszystkie zobowiązania i aktywa przenoszone między rezydentami instytucji dokonującymi bezpośrednich inwestycji a ich inwestorami bezpośrednimi. Obejmują również transfery aktywów i zobowiązań pomiędzy przedsiębiorstwami będącymi rezydentami i nierezydentami, jeżeli ostateczny dominujący członek kontroli nie jest rezydentem.

Zewnętrzne inwestycje bezpośrednie, zwane również inwestycjami bezpośrednimi za granicą, obejmują aktywa i pasywa przeniesione między bezpośrednich inwestorów i ich przedsiębiorstwami bezpośredniego inwestowania. Obejmują transfery aktywów i zobowiązań między przedsiębiorstwami będącymi rezydentami i nierezydentami, jeżeli ostateczny dominujący członek kontroli jest rezydentem. Zewnętrzne inwestycje bezpośrednie są również nazywane inwestycjami bezpośrednimi za granicą.

Dane o przepływach FDI są prezentowane również jako saldo (FDI netto): różnica między napływem kapitału do kraju sprawozdającego i odpływem 
kapitału z kraju sprawozdającego (należności minus zobowiązania między inwestorami bezpośrednimi i ich zagranicznymi podmiotami powiązanymi). Pomniejszenie wartości netto aktywów lub wzrost wartości zobowiązań netto są rejestrowane jako kredyty, natomiast wzrosty netto aktywów lub zmniejszenie netto zobowiązań są rejestrowane jako obciążenia. Stąd przepływy FDI ze znakiem ujemnym wskazują, że co najmniej jeden ze składników FDI jest ujemny i nie jest kompensowany dodatnimi wartościami pozostałych składników. Są to przypadki odwrotnej inwestycji lub dezinwestycji.

Rysunek 4. Napływ inwestycji bezpośrednich w mld USD

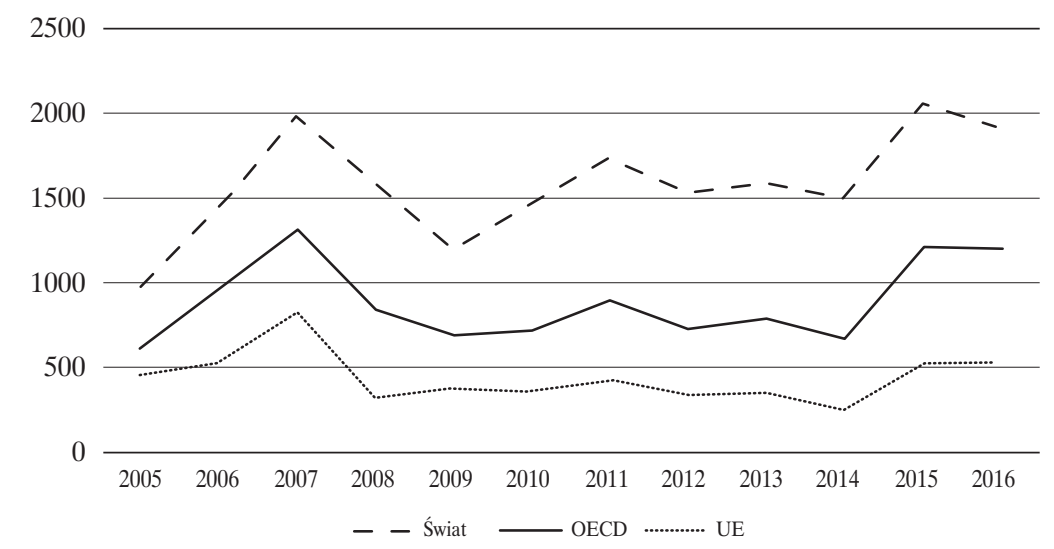

Źródło: opracowanie własne na podstawie danych OECD (www.oecd.org).

Rysunek 5. Odpływ inwestycji bezpośrednich w mld USD

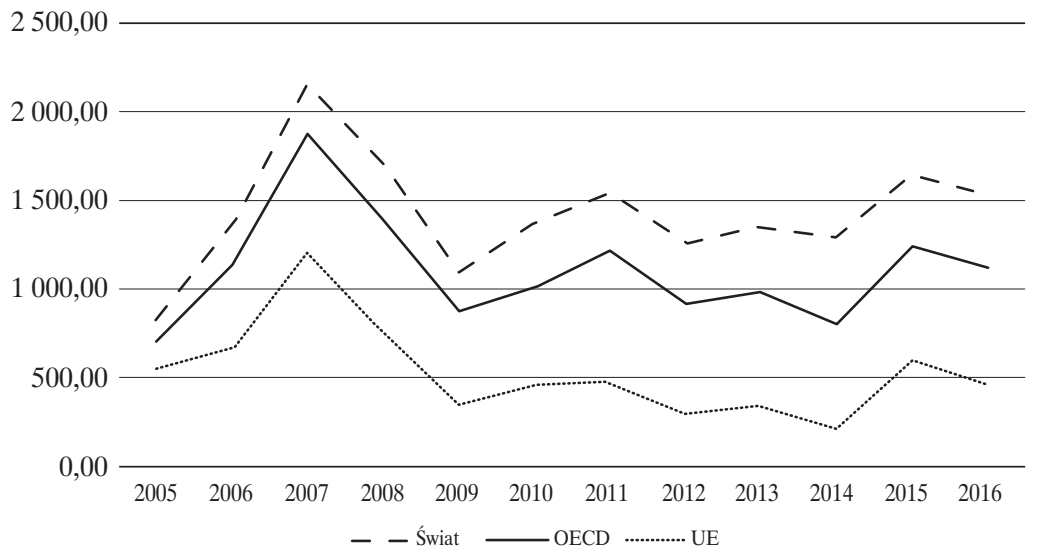

Źródło: opracowanie własne na podstawie danych OECD (www.oecd.org). 
Baza danych o FDI publikowana przez OECD obejmuje wartości rocznego strumienia napływu i odpływy inwestycji do i z poszczególnych krajów w USD, wartość rocznego salda napływu i odpływu kapitału w formie FDI oraz udział strumienia napływu FDI w PKB krajów goszczących i udział strumienia odpływu FDI w PKB krajów inwestujących.

Największy udział w napływie i odpływie kapitału w ramach FDI mają kraje OECD, przy czym ich udział w rocznych strumieniach odpływu wynosi około 90\% odpływów globalnych, podczas gdy w rocznych strumieniach napływu FDI wynosi tylko $62 \%$. Z tego wynika, że kraje OECD są w większym stopniu dostarczycielami inwestycji bezpośrednich do pozostałych krajów, natomiast w mniejszym stopniu są miejscem docelowym światowych inwestycji bezpośrednich.

L. Alfaro oraz J. Chauvin (2017) w swoich badaniach dowiedli, że rozwijające się gospodarki rosną w wyniku wzrostu inwestycji bezpośrednich, stwarzających jednocześnie szanse i zagrożenia dla krajów goszczących. W swojej analizie wykorzystali zmienne makroekonomiczne (stopę wzrostu PKB, zagregowaną produkcję, eksport) oraz mikroekonomiczne (pozytywne efekty zewnętrzne skutków ubocznych, powiązania i realokację kapitału). Korzyści gospodarcze są zróżnicowane względem poziomu rozwoju gospodarczego z tytułu napływu inwestycji bezpośrednich. Firmy zagraniczne częściej inwestują kapitał w gospodarkach słabo rozwiniętych niż w rozwiniętych, gdzie mogą gromadzić fundusze na szczeblu lokalnym. Oba typy gospodarek prawdopodobnie skorzystają na podwyżkach płac i eksporcie z powodu obecności zagranicznego kapitału, choć potencjalnie będą to różne kanały. W słabo rozwiniętych gospodarkach eksport może wzrosnąć, ponieważ firmy zagraniczne mają mniejsze ograniczenia finansowe i mogą sobie pozwolić na stały koszt eksportu, w gospodarkach rozwiniętych eksport może wynikać z tego, że firmy zagraniczne unikają większej konkurencji na rynkach lokalnych. Większe korzyści mikroekonomiczne wynikające z rozprzestrzeniania się bezpośrednich inwestycji zagranicznych, pozytywnych powiązań i presji konkurencyjnej są bardziej prawdopodobne w gospodarkach o dobrze rozwiniętych rynkach finansowych, na których lokalne firmy mogą reagować na te szanse i zagrożenia z tytułu wzrostu konkurencji poprzez inwestycje zwiększające ich produktywność.

Na rysunku 6 pokazujemy roczne strumienie napływu, a na rysunku 7 roczne strumienie odpływu FDI w skali: globalnej, OECD i EU jako procent PKB (odpowiednio: światowego, OECD i EU). Największe znaczenie w relacji do PKB mają FDI w ramach EU. Wartość inwestycji bezpośrednich, które napłynęły w roku 2007 do krajów EU wynosiła 4,60\% ich PKB, podczas gdy wartość FDI rezydentów EU za granicą stanowiła w tym roku 7,00\% PKB. A więc rezydenci EU w większym stopniu są inwestorami bezpośrednimi niż biorcami 
inwestycji zagranicznych. Dla krajów OECD te same wskaźniki w 2007 roku odpowiednio wynoszą: napływ FDI - 3,10\% PKB; odpływ FDI - 4,20\% PKB. A więc ponownie rezydenci tych krajów w większym stopniu inwestują za granicą niż są beneficjentami inwestycji zagranicznych. Jednak różnica jest znacznie niższa w porównaniu z EU.

Rysunek 6. Napływ inwestycji bezpośrednich jako procent PKB

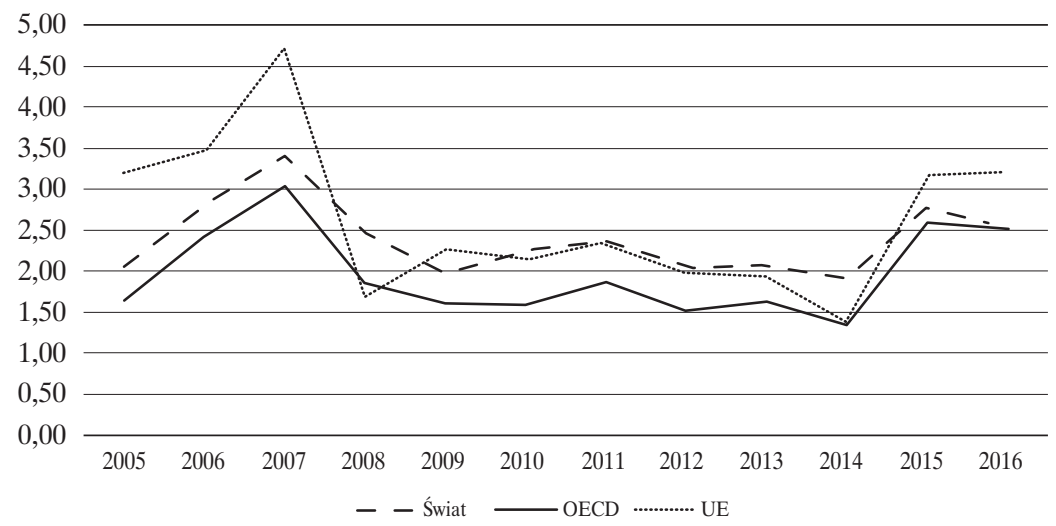

Źródło: opracowanie własne na podstawie danych OECD (www.oecd.org).

Rysunek 7. Napływ inwestycji bezpośrednich jako procent PKB

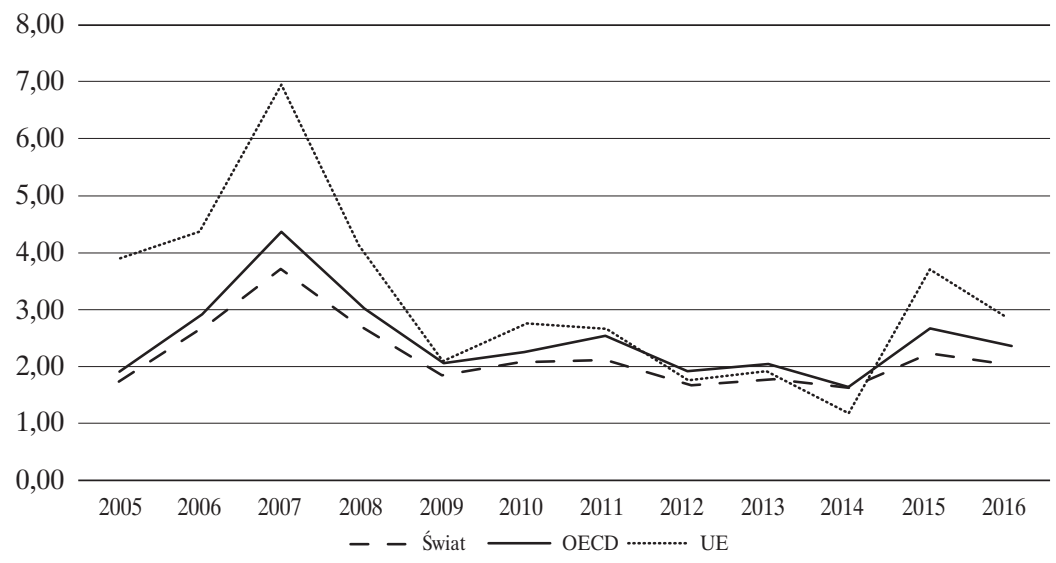

Źródło: opracowanie własne na podstawie danych OECD (www.oecd.org). 
Na rysunku 8 pokazujemy napływ FDI, na rysunku 9 zaś odpływ kapitału z trzech grup krajów OECD wyróżnionych w pierwszej części artykułu (wysoko rozwinięte, średnio rozwinięte i słabo rozwinięte). Jak poprzednio wszystkie strumienie są podawane w okresie 2005-2016. Warto zauważyć, że napływ i odpływ kapitału w ramach FDI jest bardzo wrażliwy na światowy cykl koniunkturalny, czego nie widać w grupie krajów średnio i słabo rozwiniętych. Napływ FDI wzrósł w okresie 2005-2007 z około 500 mld USD do 1100 mld USD. Wartość inwestycji bezpośrednich rezydentów krajów OECD za granicą wynosiła w 2007 roku 1,6 bln USD, co stanowiło $84 \%$ inwestycji bezpośrednich całego OECD i $71 \%$ światowych inwestycji bezpośrednich. Napływ FDI do krajów OECD wyniósł w tym roku 1,1 bln USD, co stanowiło $85 \%$ wartości napływu FDI do całego OECD i 55\% wartości globalnych FDI w tym roku. Z powyższych wskaźników wynika, że podstawowe znaczenie w ramach OECD mają FDI między rezydentami 19 najbardziej rozwiniętych krajów świata. Rezydenci tych krajów są eksporterami netto do pozostałych krajów, co wyraża się w ujemnym saldzie FDI tej grupy krajów, przedstawionym na rysunku 10. W odwrotnej sytuacji są kraje średnio i słabo rozwinięte, które mają dodatnie saldo FDI. Szczególnym beneficjentem FDI jest grupa krajów najniżej rozwiniętych, której saldo FDI jest niemalże dwukrotnie wyższe w porównaniu z grupą krajów średnio rozwiniętych. Szczegółowe wyniki zaprezentowano w tabelach 2 i 3.

Rysunek 8. Napływ inwestycji bezpośrednich w trzech grupach krajów OECD przy uwzględnieniu poziomu rozwoju gospodarczego mierzonego $\mathrm{PKB}$ per capita w mln USD

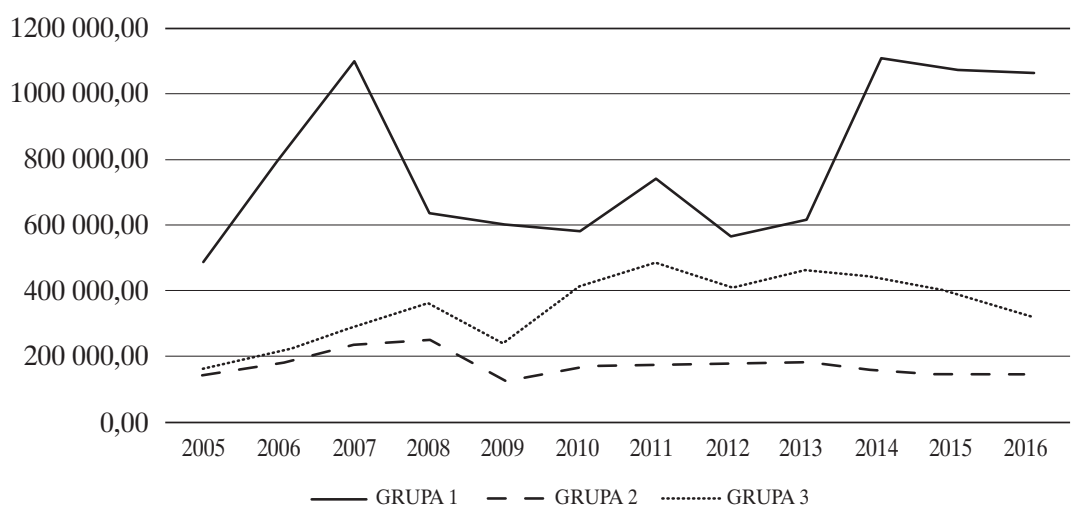

Źródło: opracowanie własne na podstawie danych OECD (www.oecd.org). 
Rysunek 9. Odpływ inwestycji bezpośrednich w trzech grupach krajów OECD przy uwzględnieniu poziomu rozwoju gospodarczego mierzonego PKB per capita $\mathrm{w}$ mln USD

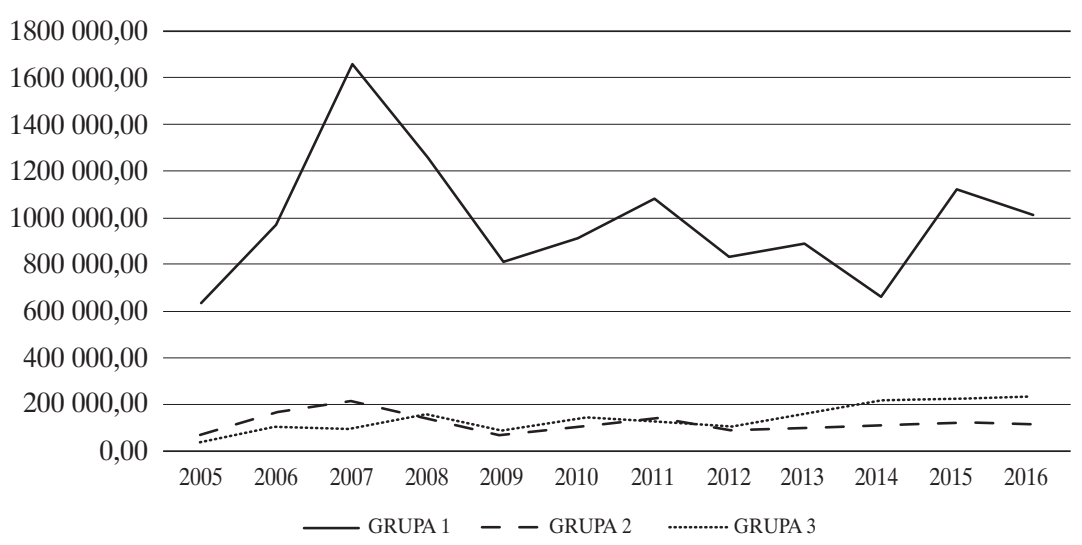

Źródło: opracowanie własne na podstawie danych OECD (www.oecd.org).

Rysunek 10. Saldo inwestycji bezpośrednich w trzech grupach krajów OECD przy uwzględnieniu poziomu rozwoju gospodarczego mierzonego $\mathrm{PKB}$ per capita 600000,00

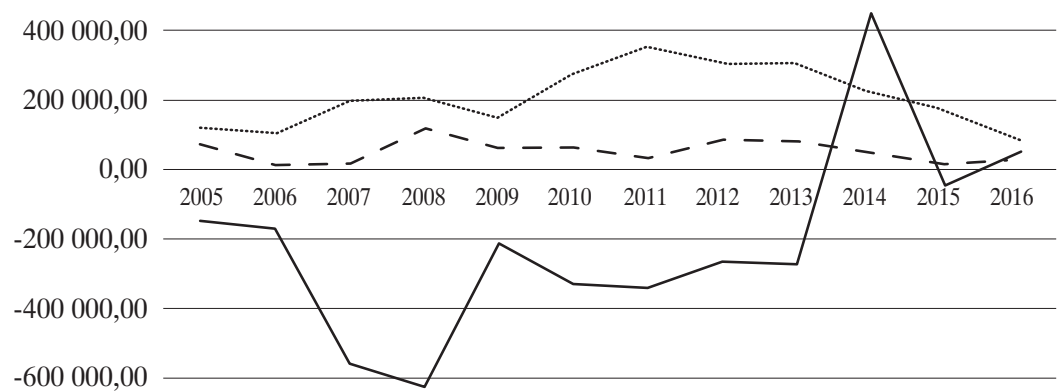

$-800000,00$

$$
\text { - GRUPA } 1-\text { GRUPA } 2 \quad \ldots \ldots \ldots \ldots \text { GRUPA } 3
$$

Źródło: opracowanie własne na podstawie danych OECD (www.oecd.org).

W badaniu przeprowadzonym przez R. Cezar i O.R. Escobar (2015) przeanalizowano powiązania między bezpośrednimi inwestycjami zagranicznymi a odległością instytucjonalną ${ }^{3}$. Zweryfikowali oni, w jaki sposób dystans instytucjonalny wpływa na bezpośrednie inwestycje zagraniczne i pokazali, że odległości instytucjonalne zmniejszają prawdopodobieństwo, że firma zainwestuje

3 Różnice pomiędzy regulacjami i instytucjami regulującymi. 
w obcym kraju, co ma związek również z wielkością inwestycji, które podejmie. Badanie przeprowadzone na danych OECD wskazuje, że aktywność FDI maleje wraz z odległością instytucjonalną. Ponadto zauważają, że firmy z gospodarek rozwiniętych łatwiej adaptują się do dystansu instytucjonalnego niż firmy z gospodarek rozwijających się.

Tabela 2. Napływ inwestycji bezpośrednich z grup I, II i III do grup I i II w mln USD

\begin{tabular}{|c|c|c|r|r|r|r|}
\hline $\begin{array}{c}\text { Kraje } \\
\text { przyjmujące }\end{array}$ & \multicolumn{2}{|c|}{ GRUPA I } & \multicolumn{2}{c|}{ GRUPA II } & \multicolumn{2}{c|}{ GRUPA III } \\
\hline $\begin{array}{c}\text { Kraje } \\
\text { wysyłające }\end{array}$ & GRUPA I & GRUPA II & GRUPA I & GRUPA II & GRUPA I & GRUPA II \\
\hline 2005 & 68341 & 22728 & 11933 & 3156 & 174 & 144 \\
\hline 2006 & 50024 & 20339 & 5902 & 2768 & 3206 & 83 \\
\hline 2007 & 123325 & 28132 & 10864 & 5695 & 906 & 35 \\
\hline 2008 & 60463 & 24204 & -11864 & 6570 & 279 & 282 \\
\hline 2009 & 69549 & 20932 & 2693 & 6074 & -1619 & 329 \\
\hline 2010 & 91608 & 25737 & 2507 & 4938 & -98 & 230 \\
\hline 2011 & 355466 & 78538 & 16896 & 7327 & 1589 & -2103 \\
\hline 2012 & 337360 & 59715 & 15593 & 3251 & 3412 & 303 \\
\hline 2013 & 637943 & 102548 & 77210 & 5694 & 12347 & 1255 \\
\hline 2014 & 398755 & 78380 & 31463 & 13313 & 19822 & 1272 \\
\hline 2015 & 870877 & 40743 & 19141 & 10394 & 1575 & 395 \\
\hline 2016 & 709703 & 116074 & 25188 & 16292 & 7451 & 1071 \\
\hline
\end{tabular}

Źródło: opracowanie własne na podstawie danych OECD (www.oecd.org).

Tabela 3. Odpływ inwestycji bezpośrednich z grup I i II i III do grup I, II, III w mln USD

\begin{tabular}{|c|r|r|r|r|r|r|}
\hline $\begin{array}{c}\text { Kraje } \\
\text { przyjmujące }\end{array}$ & \multicolumn{2}{|c|}{ GRUPA I } & \multicolumn{2}{c|}{ GRUPA II } & \multicolumn{2}{c|}{ GRUPA III } \\
\hline $\begin{array}{c}\text { Kraje } \\
\text { wysylające }\end{array}$ & GRUPA I & GRUPA II & GRUPA I & GRUPA II & GRUPA I & GRUPA II \\
\hline 2005 & 93999.50 & 83.32 & 24061.65 & 425.89 & 7659.71 & 222.50 \\
\hline 2006 & 131022.97 & 355.27 & 30079.08 & 676.51 & 10372.79 & 134.14 \\
\hline 2007 & 198611.91 & 467.78 & 26477.75 & 1142.08 & 20750.17 & 288.89 \\
\hline 2008 & 87543.86 & 413.61 & 36568.71 & 925.55 & 19596.49 & -83.17 \\
\hline 2009 & 143029.68 & -63.04 & 17421.18 & 2170.64 & 4487.36 & 280.24 \\
\hline 2010 & 129460.87 & 1139.48 & 19266.27 & -139.63 & 6712.58 & $-3,75$ \\
\hline 2011 & 405668.24 & 42001.20 & 21922.29 & 3332.72 & 10119.23 & 194.26 \\
\hline
\end{tabular}


cd. tabeli 2

\begin{tabular}{|c|r|r|r|r|r|r|}
\hline $\begin{array}{c}\text { Kraje } \\
\text { przyjmujące }\end{array}$ & \multicolumn{2}{|c|}{ GRUPA I } & \multicolumn{2}{c|}{ GRUPA II } & \multicolumn{2}{c|}{ GRUPA III } \\
\hline $\begin{array}{c}\text { Kraje } \\
\text { wysylające }\end{array}$ & GRUPA I & GRUPA II & GRUPA I & GRUPA II & GRUPA I & GRUPA II \\
\hline 2012 & 314797.58 & 1647.07 & 35197.69 & 2186.47 & 14596.41 & 428.15 \\
\hline 2013 & 567517.90 & 7785.97 & 79522.83 & 8911.37 & 27716.08 & 878.87 \\
\hline 2014 & 491038.61 & 24053.40 & 59599.13 & 21673.86 & -96.58 & 971.46 \\
\hline 2015 & 774445.08 & 8577.26 & 36172.76 & 8936.24 & 15702.54 & 1980.20 \\
\hline 2016 & 676821.75 & 97956.83 & 72499.14 & 6566.18 & 9926.59 & 33.81 \\
\hline
\end{tabular}

Źródło: opracowanie własne na podstawie danych OECD (www.oecd.org).

Badania M. Irandoust (2016) przeprowadzone na grupie krajów bałtyckich pomiędzy FDI oraz zmianami strukturalnymi wykazały, że poprzez promowanie wzrostu i reform strukturalnych kraje będące beneficjentami mogą zachęcać do napływu bezpośrednich inwestycji zagranicznych, co z kolei może wpływać na wzrost. Wskazali ponadto na występowanie sprzężenia zwrotnego pomiędzy tymi dwiema zmiennymi.

Rysunek 11. Saldo inwestycji bezpośrednich w podziale na sektory w I grupie krajów w mln USD

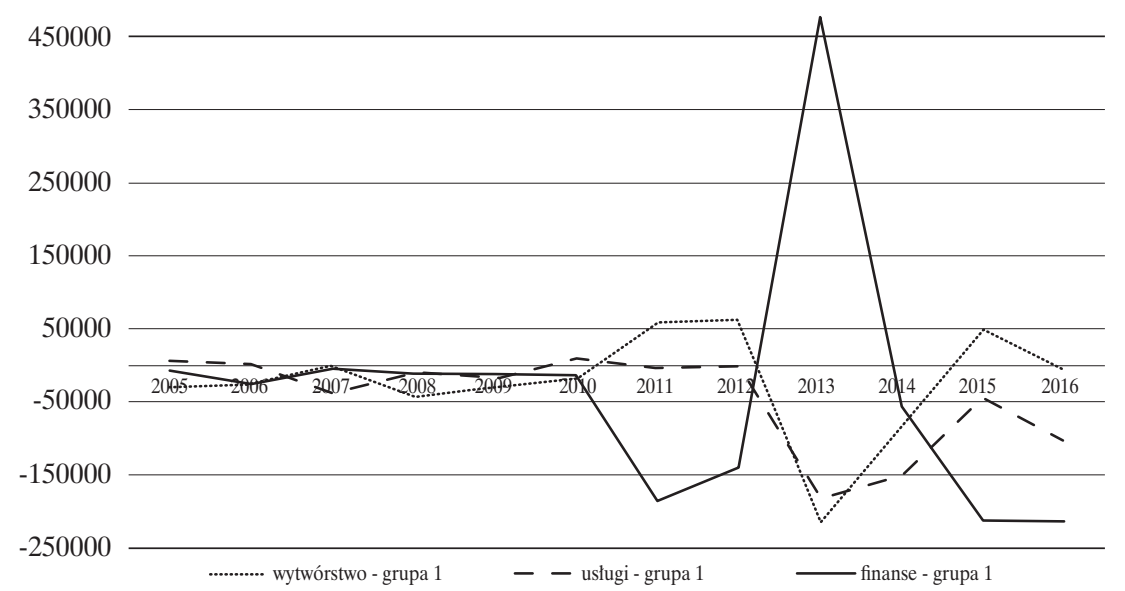

Źródło: opracowanie własne na podstawie danych OECD (www.oecd.org). 
Przeprowadzona analiza jest zgodna z założeniami Nowej Ekonomii Strukturalnej (Lin, 2010; 2012). Okazało się, że w zależności od poziomu rozwoju gospodarczego optymalna struktura przemysłowa ulega zmianom. Zmianom ulega również forma, z punktu widzenia gałęzi gospodarki, napływu środków z inwestycji bezpośrednich. W zaistniałej sytuacji można domniemywać, że w zależności od poziomu rozwoju gospodarczego kraje powinny inwestować zarówno w „miękką”, jak i w „twardą” infrastrukturę. Jednocześnie, zgodnie z założeniem wspomnianej teorii, można domniemywać, że w procesie ciągłości następuje ciągły wzrost gospodarczy przedstawiony przez nas jako teoria „wyścigu krajów”. Zmiana w zależności od rodzaju sektora, w którym dokonywane są inwestycje bezpośrednie powoduje stopniowy wzrost gospodarczy. W związku z tym kraje powinny dostosowywać swoje inwestycje w dany sektor w zależności od poziomu rozwoju gospodarczego. Ponadto wpływ kryzysu finansowego na alokację inwestycji bezpośrednich w poszczególnych gospodarkach pokazuje, że na każdym danym etapie rozwoju rynek jest podstawowym mechanizmem efektywnego alokowania zasobów. W skutek tego wraz ze wzrostem poziomu gospodarczego, zgodnie z Nową Ekonomią Strukturalną, gospodarki wymagają modernizacji przemysłowej i odpowiednich ulepszeń w „twardej” i „miękkiej” infrastrukturze na każdym etapie. Taka modernizacja pociąga za sobą znaczne efekty zewnętrzne dla kosztów transakcyjnych firm i zwrotów z inwestycji kapitałowych. W związku z tym, oprócz skutecznego mechanizmu rynkowego, rząd powinien odgrywać aktywną rolę w ułatwianiu modernizacji przemysłowej i ulepszaniu infrastruktury.

Przeprowadzone badania wskazują na dwie gospodarki o szczególnym zainteresowaniu w tym względzie, tj. Chiny i Indie, zarówno ze względu na swoją wielkość, jak i bardzo szybki wzrost. R. Dekle i G. Vandenbroucke (2012, s. 119-135) badali strukturalną transformację w Chinach w latach 1978-2003. Odkryli, że zróżnicowany sektorowy wzrost produktywności i zmniejszenie względnej wielkości chińskiego rządu spowodowały większość transformacji strukturalnej, ale spowolniły ruch w rolnictwie. V. Rubina (2012, s. 163-177) badała transformację strukturalną w Indiach w latach 1980-2005 i stwierdziła, że wzrost był najszybszy w usługach. Udowodniła, że model trójsektorowy może uwzględniać zmiany w sektorowej wartości dodanej, ale nie w udziałach w zatrudnieniu. C.M. Betts i in. (2011), M. Sposi (2011) i M. Teignier (2012) twierdzą, że handel międzynarodowy przyspieszył przejście gospodarki z rolnictwa do przemysłu i usług. Teignier (2012) dowiódł, że efekt międzynarodowych inwestycji odegrałby jeszcze większą rolę, gdyby Korea Południowa nie wprowadziła jednocześnie polityki ochrony rolnictwa. 
Praca D.W. Jorgenson i M.P. Timmer (2011, s. 1-29), opierająca się na badaniu Unii Europejskiej, Japonii i USA, wykazuje znaczną niejednorodność usług. Finanse i usługi biznesowe odznaczają się niskim wzrostem wydajności i zwiększają udział w zatrudnieniu i PKB, przy czym usługi dystrybucyjne mają szybki wzrost produktywności i stały udział. M. Duarte i D. Restuccia (2010, s. 129-173) studiują różnice między tradycyjnymi ${ }^{4}$ i nietradycyjnymi usługami. W przypadku usług tradycyjnych zauważają, że cena względna wzrasta, a realny udział wydatków maleje wraz z przychodami, podczas gdy w przypadku usług nietradycyjnych są przeciwne. D. Lagakos i M.E. Waugh (2013, s. 948-980) twierdzą, że uwzględnienie heterogenicznej jakości pracy w różnych sektorach dowodzi, że kraje ubogie wydają się mieć szczególnie niską wydajność pracy w rolnictwie.

B. Herrendorf, R. Rogerson, A. Valentinyi (2014, s. 855-941) wskazują, że nieodpowiednio dobrane polityki strukturalne mogą zniekształcać alokację zasobów w różnych sektorach. Zgodnie z Nową Ekonomią Strukturalną transformacja strukturalna powinna dążyć przy wykorzystaniu interwencji państwa do rozwoju specyficznych sektorów mających największy potencjał rozwoju (Ketels, 2017). Założenia dotyczące rentowności w ekonomii neoklasycznej można złagodzić, analizując kwestie rozwoju i transformacji w gospodarkach socjalistycznych, transformacyjnych i rozwijających się (Lin, 2015).

Rysunek 12. Saldo inwestycji bezpośrednich w podziale na sektory w II grupie krajów w mln USD

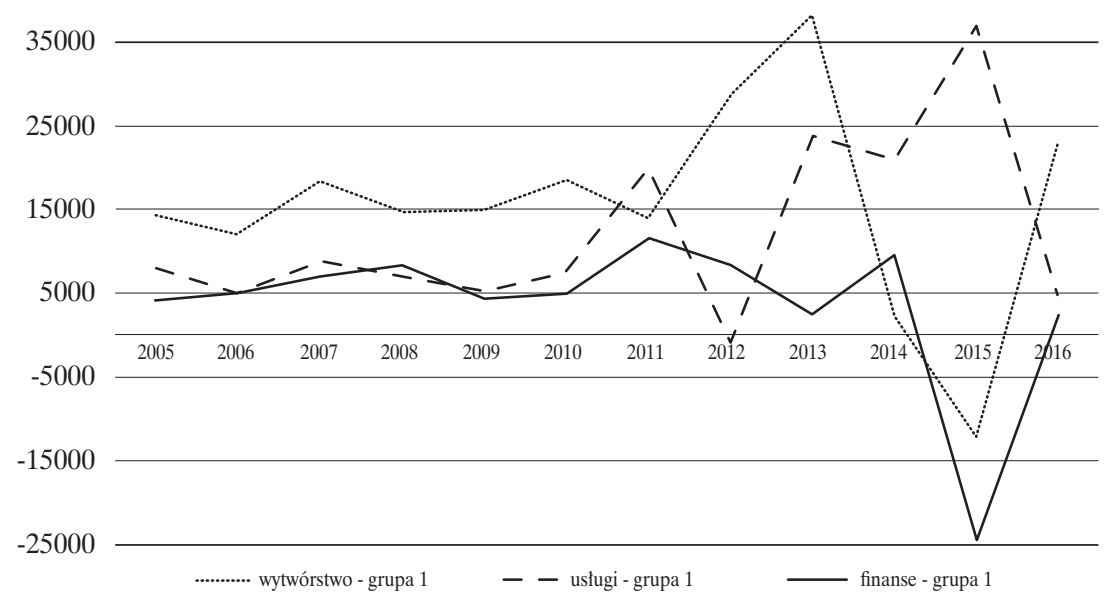

Źródło: opracowanie własne na podstawie danych OECD (www.oecd.org).

4 Tj. usługi tradycyjne to: usługi domowe i edukacja, zdrowie, mieszkalnictwo, nietradycyjne zaś to: komunikacja, usługi transportowe, ubezpieczeniowe i finansowe oraz usługi rekreacyjne i kulturalne. 
Następnie postanowiono zweryfikować wzajemne zależności pomiędzy saldem inwestycji bezpośrednich a realną stopą wzrostu PKB i odwrotnie. W celu przeprowadzenia weryfikacji wspomnianej zależności zebrano dane roczne z Banku Światowego dla lat 1970-2017 dla 165 krajów. Do badania wykorzystano statyczne modele panelowe. Do weryfikacji poprawności wyboru modelu zastosowano test Hausamana, Breuscha-Pagana. Wybór modelu panelowego podyktowany był jednoczesnym posiadaniem cech danych przekrojowych, czyli danych dla krajów oraz szeregów czasowych. Model prezentujący wpływ realnej stopy wzrostu PKB na saldo inwestycji bezpośrednich do PKB został zaprezentowany poniżej:

$$
f d i_{i t}=\alpha+p k b_{i t}+u_{i t}+e_{i t}
$$

$f d i_{i t}$ - stosunek salda inwestycji bezpośrednich do PKB $i$-tego kraju w okresie $t$, $p k b_{i t}$ - realna stopa wzrostu PKB $i$-tego kraju w okresie $t$,

$\alpha$ - stała,

$u_{i t}$ - błąd losowy zawierający stałe w czasie nieobserwowane charakterystyki, $e_{i t}$ - błąd czysto losowy.

Natomiast model prezentujący wpływ salda inwestycji bezpośrednich na realną stopę wzrostu PKB został zaprezentowany poniżej:

$$
p k b_{i t}=\alpha+f d i_{i t}+u_{i t}+e_{i t}
$$

W tabeli 4 zaprezentowano wyniki estymacji.

Wyniki estymacji przeprowadzone dla testu Hausmana sugerują poprawność wykorzystania statycznego modelu panelowego z efektami zmiennymi. Natomiast otrzymane wyniki dla testu Bresucha-Pagana wskazują na zasadność wykorzystania modelu panelowego wobec modelu liniowego w obu przypadkach. Będąc świadomi słabego dopasowania modelu, nie dokonujemy bezpośredniej analizy otrzymanych wyników. Naszym celem była jedynie weryfikacja istotności wzajemnych zależności pomiędzy saldem inwestycji bezpośrednich a realną stopą wzrostu PKB i odwrotnie. Przeprowadzone badanie dowiodło wysoce istotnej statystycznie zależności pomiędzy obiema zmiennymi. Niski poziom dopasowania modelu należy tłumaczyć wpływem innych istotnych czynników oddziałujących zarówno na saldo inwestycji bezpośrednich, jak i realną stope wzrostu PKB. Otrzymane wyniki symulacji są zgodne z badaniami C.K. Volos, I.M. Kyprianidis, I.N. Stouboulos (2015, s. 1-7). 
Tabela 4. Wyniki estymacji wpływu realnej stopy wzrostu PKB na saldo inwestycji bezpośrednich (1) oraz salda inwestycji bezpośrednich na realną stopę wzrostu PKB

\begin{tabular}{|c|c|c|c|c|}
\hline \multirow{2}{*}{ Zmienna zależna } & \multicolumn{2}{|c|}{ FDI netto (1) } & \multicolumn{2}{|c|}{ Realna stopa wzrostu PKB (2) } \\
\hline & Coef. & $\mathbf{P}>\mathrm{z}$ & Coef. & $P>z$ \\
\hline Zmienna niezależna & .123695 & 0.000 & .0306341 & 0.000 \\
\hline$\alpha$ & 3.500842 & 0.000 & 3.704615 & 0.000 \\
\hline Liczba obserwacji & \multicolumn{2}{|c|}{5911} & \multicolumn{2}{|c|}{5911} \\
\hline Liczba grup & \multicolumn{2}{|c|}{165} & \multicolumn{2}{|c|}{165} \\
\hline Test F & \multicolumn{2}{|c|}{0.0000} & \multicolumn{2}{|c|}{0.0000} \\
\hline Hausman & \multicolumn{2}{|c|}{0.1306} & \multicolumn{2}{|c|}{0.1947} \\
\hline $\mathrm{BP}$ & \multicolumn{2}{|c|}{0.0000} & \multicolumn{2}{|c|}{0.0000} \\
\hline \multicolumn{5}{|l|}{$\mathrm{R}$ squared } \\
\hline Wewnątrz & \multicolumn{2}{|c|}{0.0034} & \multicolumn{2}{|c|}{0.0034} \\
\hline Pomiędzy & \multicolumn{2}{|c|}{0.0240} & \multicolumn{2}{|c|}{0.0240} \\
\hline Całość & \multicolumn{2}{|c|}{0.0070} & \multicolumn{2}{|c|}{0.0070} \\
\hline Model & \multicolumn{2}{|c|}{ z efektami zmiennymi } & \multicolumn{2}{|c|}{ z efektami zmiennymi } \\
\hline
\end{tabular}

Legenda: liczba grup - liczba krajów poddanych analizie; test F - test Fishera; Hausman - test Hausmana; $\mathrm{BP}$ - test Breuscha - Pagana; $\mathrm{R}$ squared - skorygowany $\mathrm{R}^{2}$ : wewnątrz - skorygowany $\mathrm{R}^{2}$ wewnątrz grupy krajów; pomiędzy - skorygowany $\mathrm{R}^{2}$ pomiędzy grupami krajów; całość - łączny skorygowany $\mathrm{R}^{2}$. Źródło: opracowanie własne.

K. Dellis, D. Sondermann, I. Vansteenkiste (2017) wskazali na wpływ zmian strukturalnych, takich jak koszty pracy, wielkość rynku docelowego (zgodnie z jego wartością), działalność gospodarcza, otwartość handlu kraju będącego beneficjentem oraz jego tendencja do opodatkowania. S. Estrin i M. Uvalic (2013) dowiedli, że przy uwzględnieniu wielkości gospodarki, odległości, jakości instytucjonalnej i perspektyw członkostwa w UE, kraje Bałkanów Zachodnich charakteryzują się niższym napływem bezpośrednich inwestycji zagranicznych. Kwestie te mają duże znaczenie polityczne dla gospodarek bałkańskich.

\section{Podsumowanie}

Jesteśmy w pełni przekonani, że bezpośrednie inwestycje zagraniczne nie są jedynym, ani nawet głównym, czynnikiem wpływającym na wzrost gospodarczy, jak również tempo wzrostu gospodarczego nie w pełni determinuje napływ i odpływ tych inwestycji. Świadczą o tym niskie współczynniki korelacji wielorakiej w obu zaprezentowanych modelach. Naszym celem nie było jednak pełne 
wyjaśnienie determinantów tych dwóch zmiennych. Do tego celu należałoby zastosować modele wieloczynnikowe. Jednak oba modele jednoczynnikowe udowadniają hipotezę o istnieniu dodatniego sprzężenia zwrotnego pomiędzy tymi zmiennymi. Napływ bezpośrednich inwestycji pozytywnie wpływa na tempo wzrostu gospodarczego, a wzrost gospodarczy zachęca inwestorów zagranicznych do inwestowania. Oznacza to, że FDI działają procyklicznie. Wspomagają wzrost gospodarczy, ale również pogłębiają recesje i spadek PKB. Jeżeli zahamowanie bądź spadek tempa wzrostu gospodarczego następuje na skutek szoków wewnętrznych, bądź zewnętrznych to reakcja inwestorów zagranicznych pogłębia ten spadek. Zjawisko to bardzo wyraźnie wystąpiło w roku 2018 w przypadku Argentyny i Turcji.

Zjawisko to zaobserwowano już wcześniej w relacji kredytów bankowych i wzrostu gospodarczego. W ramach Bazylei III wprowadzono dla przeciwdziałania procyklicznemu charakterowi kredytów specjalne antycykliczne bufory kapitałowe w obliczaniu współczynnika wypłacalności. W przeciwieństwie jednak do sektora bankowego, FDI nie są regulowane ani przez państwa pochodzenia kapitału, ani przez państwa goszczące.

\section{Bibliografia}

Alfaro, L. i Chauvin, J. (2017). Foreign Direct Investment, Finance, and Economic Development. Harvard Business School Working Papers.

Betts, C.M., Giri, R. i Rubina, V. (2011). Trade, Reform, and Structural Transformation in South Korea. University of Southern California Working Paper.

Cezar, R. i Escobar, O.R. (2015). Institutional Distance and Foreign Direct Investment. Banque de France, December.

Dekle, R., Vandenbroucke, G. (2012). A Quantitative Analysis of China's Structural Transformation. Journal of Economic Dynamics and Control, 36, 119-135.

Dellis, K., Sondermann, D. i Vansteenkiste, I. (2017). Determinants of FDI inflows in advanced economies: Does the quality of economic structures matter? European Central Bank Working Paper, No. 2066.

Duarte, M. i Restuccia, D. (2010). The Role of the Structural Transformation in Aggregate Productivity. Quarterly Journal of Economics, 125, 129-173.

Estrin, S. i Uvalic, M. (2013). Foreign direct investment into transition economies: Are the Balkans different? London School of Economics Europe in Questions Working Paper, No. 63.

Herrendorf, B., Rogerson, R. i Valentinyi, A. (2014). Growth and Structural Transformation. Handbook of Economic Growth, 2, 855-941.

https://data.oecd.org

Irandoust, M. (2016). Structural changes, FDI, and economic growth: evidence from the Baltic states. Journal of Economic Structures, 5(14). 
Jorgenson, D.W. i Timmer, M.P. (2011). Structural Change in Advanced Nations: A New Set of Stylised Facts. Scandinavian Journal of Economics, 113, 1-29.

Ketels, C. (2017). Structural transformation: a competitiveness-based view. African Development Bank Group Working Papers, No. 258.

Lagakos, D. i Waugh, M.E. (2013). Selection, Agriculture, and Cross-Country Productivity Differences. The American Economic Review, 103(2), 948-980.

Lin, J.Y. (2010). New Structural Economics A Framework for Rethinking Development. World Bank Policy Research Working Paper, No. 5197.

Lin, J.Y. (2012). New Structural Economics. A Framework for Rethinking Development and Policy. World Bank.

Lin, J.Y. (2017). New Structural Economics and 2017 industrial policies catching-up economics. W: J.Y. Lin, A.Z. Nowak (red.), New Structural Economics for less advanced countries. Warszawa: Wydawnictwo Naukowe Wydziału Zarządzania UW.

Lin, J.Y. (2015). The Washington Consensus revisited: a new structural economics perspective. Journal of Economic Policy Reform, 18.

Rubina, V. (2012). Can Total Factor Productivity Explain Value Added Growth in Services. Journal of Development Economics, 99, 163-177.

Sposi, M. (2011). Evolving Comparative Advantage, Structural Change, and the Composition of Trade. University of Iowa Working Paper.

Teignier, M. (2012). The Role of Trade in Structural Transformation. Universidad de Alicante Working Paper.

Volos, C.K., Kyprianidis, I.M. i Stouboulos, I.N. (2015). The Effect of Foreign Direct Investment in Economic Growth from the Perspective of Nonlinear Dynamics. Journal of Engineering Science and Technology Review, 8(1), 1-7. 